\title{
A painful soft tissue mass secondary to impingement of a metal on polyethylene bearing total hip arthroplasty
}

\author{
Griffiths-Jones William, Williams Daniel
}

Department of Orthopaedics, Royal Cornwall Hospital, Truro, Cornwall, UK

\section{Correspondence to Griffiths-Jones William, will@griffiths-jones.co.uk}

Accepted 23 April 2014
CrossMark

To cite: William G-J, Daniel W. BMJ Case Rep Published online: [please include Day Month Year] doi:10.1136/bcr-2012008085

\section{SUMMARY}

A 60-year-old woman underwent a metal on polyethylene total hip replacement. The patient experienced pain and sustained multiple dislocations over the following 2 years and was referred for consideration of revision surgery. At the time of revision surgery it was found that there was a significant amount of polyethylene wear likely to have arisen as a result of the neutral cup placement and subsequent anterior impingement. A large cystic mass was excised and on histology was found to contain tissue with a lymphocytic infiltrate with a large amount of intracellular birefringent debris, consistent with polyethylene. The appearance of such masses is well reported as pseudotumours in metal-on-metal hip replacements but as yet their aetiology is unknown. We believe that the formation of the mass in this case could represent a model by which these pseudotumours occur.

\section{BACKGROUND}

The cause of recently reported pseudotumour formation in patients with metal-on-metal hip replacements is unknown. There has been a postulated association between raised serum metal ions and pseudotumour formation. We present a case where polyethylene debris secondary to significant impingement of a metal on polyethylene bearing resulted in a painful inflammatory mass.

\section{CASE PRESENTATION}

A 60-year-old woman underwent a metal on polyethylene total hip replacement for osteoarthritis at another centre. A posterior approach was utilised; surgery was uneventful and the wound healed without complication. Postoperative pain improved and the patient was discharged. The patient sustained a first-time posterior dislocation at 10 months. Subsequently the hip dislocated a further seven times, all requiring closed reduction under general anaesthetic.

The patient was referred for consideration of hip revision surgery at 2 years. On retrospective questioning the patient revealed that the hip had become painful 10 months postoperatively at around the time of her first dislocation. The patient described constant groin pain rated 4 of 10 on a visual analogue scale with no element of startup pain. Examination revealed equal leg lengths, discomfort on full flexion and internal rotation, grade 5 power of hip flexion and hip abduction and no distal neurovascular deficit.

\section{INVESTIGATIONS}

A 60-year-old woman underwent a metal on polyethylene total hip replacement for osteoarthritis at another centre. A posterior approach was utilised; surgery was uneventful and the wound healed without complication. Postoperative pain improved and the patient was discharged. The patient sustained a first-time posterior dislocation at 10 months. Subsequently the hip dislocated a further seven times all of which required closed reduction under general anaesthetic.

The patient was referred for consideration of hip revision surgery at 2 years. On retrospective questioning the patient revealed that the hip had become painful 10 months postoperatively at around the time of her first dislocation. The patient described constant groin pain rated 4 out of 10 on a visual analogue scale with no element of startup pain. Examination revealed equal leg lengths, discomfort on full flexion and internal rotation, grade 5 power of hip flexion and hip abduction and no distal neurovascular deficit.

$\mathrm{X}$-ray films revealed well-fixed uncemented components (Plus Orthopaedics EP SL Plus size 4 stem with a $28 \mathrm{~mm}$ Cobalt Chromium Molybdenum (CoCrMo) head and EP fit Plus size 54 cup with polyethylene (PE) liner) with no sign of early loosening or osteolysis. Inclination of the cup measured $48^{\circ}$ on an adequately taken anteroposterior pelvic film. While it is difficult to assess anteversion of the cup in the axial plane from the lateral radiograph taken in the sagittal plane, the version of the cup did appear significantly neutral predisposing to anterior impingement and posterior dislocation. Version of the stem was satisfactory (figures 1 and 2). Blood

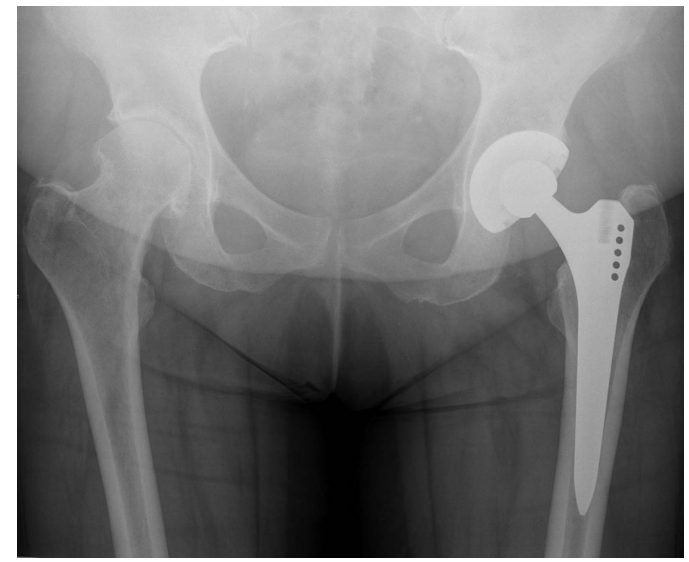

Figure 1 Pre-revision surgery anteroposterior X-ray film. 


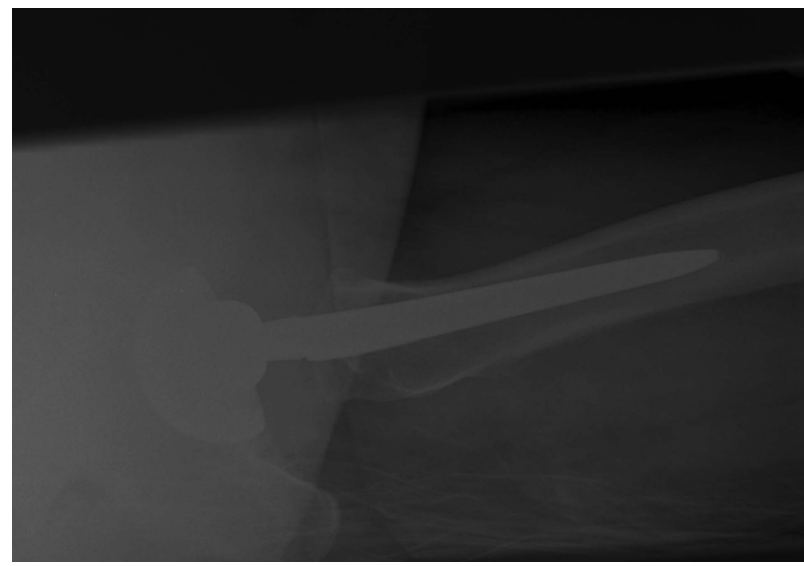

Figure 2 Pre-revision surgery lateral X-ray film.

investigations revealed a white cell count of 11 , a $\mathrm{C}$ reactive protein of 17 and an erythrocyte sedimentation rate of 29 . An aspirate of the hip performed under local anaesthetic revealed no growth and therefore infection was deemed unlikely. ${ }^{1}$ Injection of local anaesthetic into the hip joint eliminated the groin pain for $3 \mathrm{~h}$.

\section{TREATMENT}

Following discussion of the risks and benefits, the patient was listed for revision surgery. The same scar was utilised and extended and the hip exposed using a posterior approach. Assessment revealed impingement of the femoral component neck on the anterior rim of the acetabulum leading to dislocation at $70^{\circ}$ flexion and $10^{\circ}$ of internal rotation. The cup and the stem were well fixed. Satisfactory stem position was confirmed but the cup was underanteverted into a more neutral position by between $15^{\circ}$ and $20^{\circ}$ when compared with the transverse acetabular ligament. The most striking finding, however, was the absence of the anterior $160^{\circ}$ of the polyethylene rim of a liner that originally had polyethylene present at a uniform height above the entire circumference of the acetabular shell (figure 3). Arising from this arc and projecting forwards anterior to psoas tendon was a large cystic mass, which once removed, measured $70 \times 60 \times 30 \mathrm{~mm}$ (figure 4).

The cup was excised using a short-curved and long-curved explant blade that also removed $1 \mathrm{~mm}$ of the bone that was

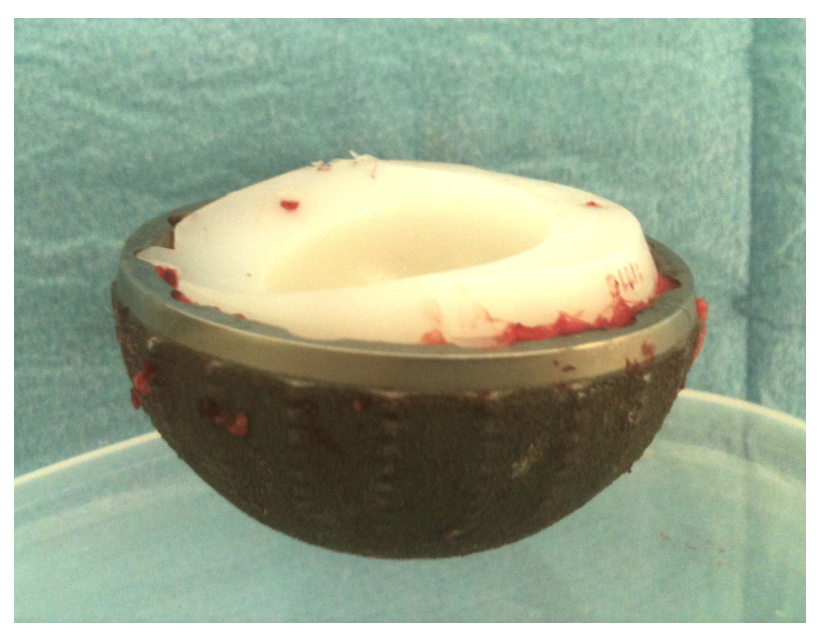

Figure 3 Clinical photograph showing the excised cup with marked wear of the anterior rim of polyethylene.

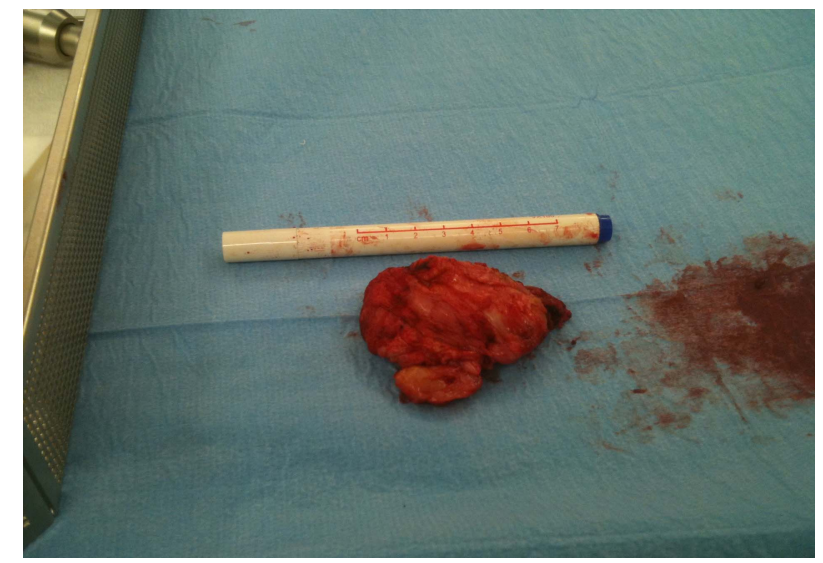

Figure 4 Clinical photograph of the excised mass.

ingrown into the superior one-third of the acetabular shell. There was no significant membrane to remove from the acetabular bone. The anterior mass was excised and sent for microbiological and histological examination. Five further tissue samples were taken and sent for microbiological examination. Clinically there was no gross sign of infection. The acetabulum was reconstructed with a $62 \mathrm{~mm}$ peripherally expanded modular shell (Zimmer Trilogy cup) that achieved very good press fit. This fixation was supplemented with three screws and a $32 \mathrm{~mm}$ internal diameter highly cross-linked polyethylene (Zimmer longevity) liner with a $10^{\circ}$ lip was inserted. The hip was reduced and on-table assessment confirmed good stability and equal leg lengths (figure 5).

Postoperative intravenous antibiotics were continued until the culture results were returned at $72 \mathrm{~h}$. There was no bacterial growth from any of the five samples. Histological examination of the cystic mass revealed fibroconnective tissue with a lymphocytic infiltrate and reactive tissue changes. Interestingly there were significant amounts of birefringent material consistent with polyethylene debris (figures 6 and 7). ${ }^{2}$

\section{OUTCOME AND FOLLOW-UP}

The patient was followed up routinely at 6 weeks, 3 months and 1 year and has experienced satisfactory relief from her pain with no further dislocations.

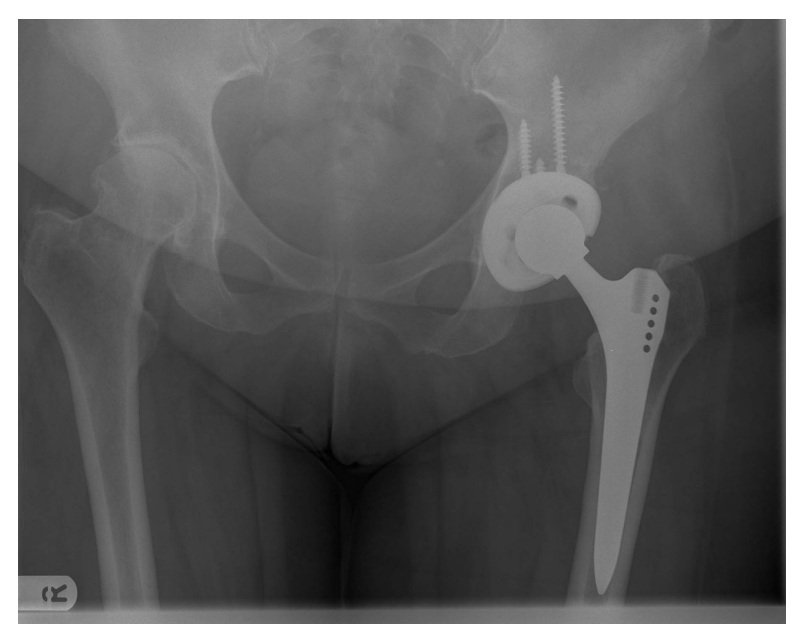

Figure 5 Postoperative anteroposterior X-ray film. 


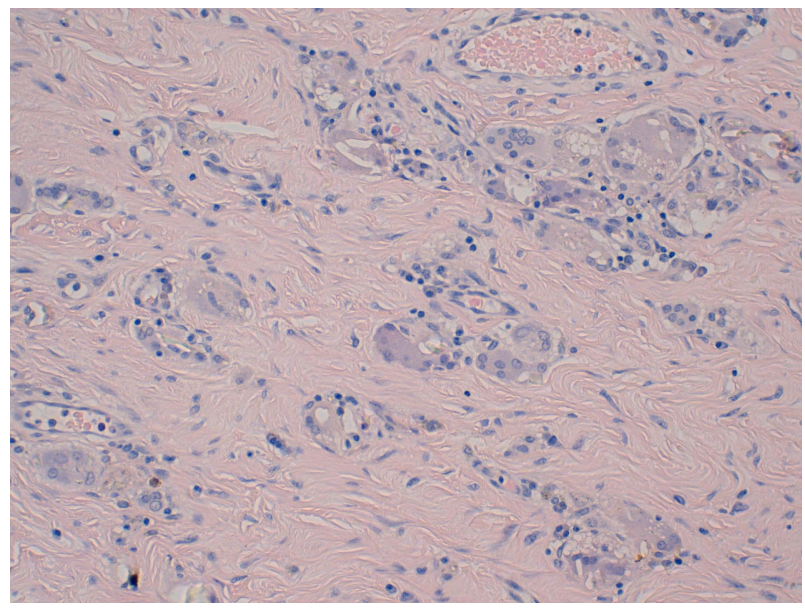

Figure 6 Clinical photograph of a histology slide showing lymphocytic infiltrate.

\section{DISCUSSION}

Hip replacement has remained the treatment of choice for advanced osteoarthritis and other degenerative conditions of the hip. Metal-on-metal hip replacement was reintroduced in the early 1990 s as a 'hard' bearing surface to minimise wear and resulting osteolysis. Early and medium term clinical results for metal-on-metal hip resurfacing (HRA) ${ }^{3} 4$ and metal-on-metal total hip arthroplasty (THA) ${ }^{5-7}$ have been encouraging. The elevated serum metal ions detected in association with these implants ${ }^{8-11}$ have resulted in no proven systemic ill effects in the long term. ${ }^{12} 13$ There have, however, been isolated reports of benign but locally destructive masses closely associated with metal-on-metal HRA and THA. ${ }^{14-16}$

The Oxford Group recently reported their total series of 1419 HRAs that included 26 symptomatic so-called pseudotumours that required revision surgery. At 8 years the cumulative revision rate for pseudotumours was $4 \%$. In women the rate was $9 \%$ and in men it was only $0.5 \% .{ }^{17}{ }^{18}$ Possible reasons for this eightfold higher revision rate for pseudotumours in women include smaller component size requirement and an increased

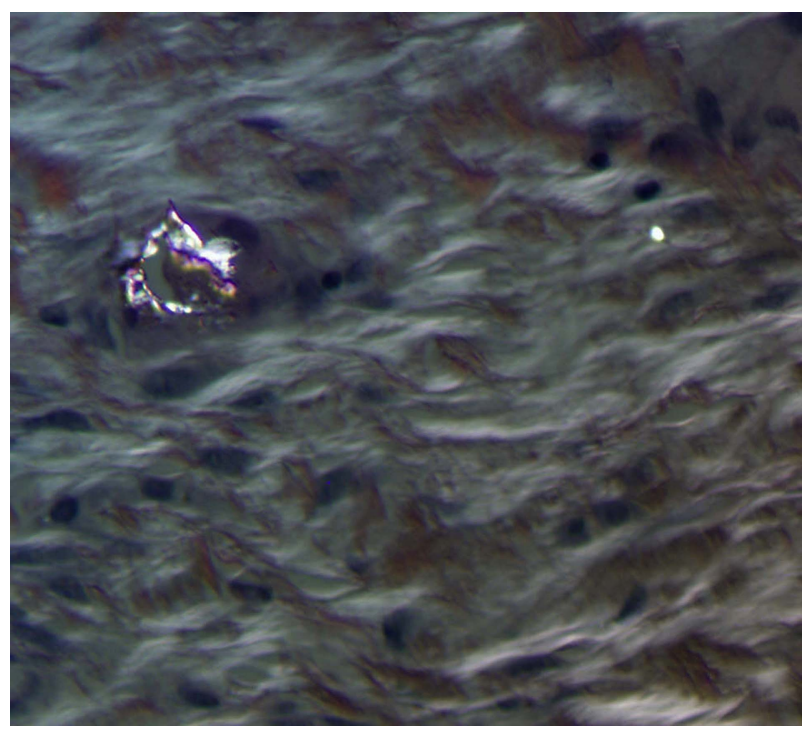

Figure 7 Clinical photograph of a histology slide under polarised light showing birefringent debris. prevalence of metal allergy secondary to wearing jewellery. ${ }^{19}$ An increased range of motion in women may also result in impingement and edge loading. While smaller bearing surfaces are less likely to achieve hydrodynamic lubrication ${ }^{20}$ they are also less likely to have adequate superior cover. A weight bearing arc of coverage of less than $10 \mathrm{~mm}$, which is a function of cup inclination, bearing size and component design, leads to a higher level of serum metal ions. ${ }^{21}$ Smaller components also increase the risk of component malalignment that leads to impingement within a physiological range of motion. ${ }^{22}$

There have been reports of solid, cystic and fluid masses associated with metal on polyethylene THA. ${ }^{23}$ Many of these local soft tissue abnormalities are small and often form only minor fluid collections that do not cause symptoms. The overall incidence and any causal relationships have, therefore, not previously been described. Patients with this bearing surface do not usually present with painful symptoms until macrophage-driven osteolysis has significantly affected the bone surrounding the implants. ${ }^{25}$ Patients tend to present with symptoms of instability or overt dislocation if component malposition leads to impingement within a physiological range of motion.

This report describes a large inflammatory mass containing significant amounts of polyethylene debris adjacent to the edge of a polyethylene liner that had been worn flat. While the patient had repeated dislocations, constant groin pain was also a significant symptom. A malpositioned 'neutral' cup had resulted in repeated impingement of the metal neck of the stem on the edge of the polyethylene liner within a physiological range of motion. The debris produced from a metal on polyethylene bearing and the histological reaction to this debris is different to the pathological process that results in pseudotumour formation in metal-on-metal arthroplasty. The mechanism of edge loading and impingement producing significant volumes of debris resulting in a localised inflammatory process and a symptomatic mass may, however, be similar. The precise positioning of THA and HRA components is key to the long-term success of hip replacement surgery.

\section{Learning points}

- Pseudotumour formation in metal-on-metal total hip replacement is well documented but the cause remains unknown.

- In our case, an inflammatory mass similar to these pseudotumours was found to contain lymphocytes with intracellular polyethylene.

- We believe that this provides a possible explanation for the formation of these pseudotumours.

Competing interests None.

Patient consent Obtained.

Provenance and peer review Not commissioned; externally peer reviewed.

\section{REFERENCES}

1 Della Valle C, Parvizi J, Bauer TW, et al. American Academy of Orthopaedic Surgeons Clinical Practice Guideline on: the diagnosis of periprosthetic joint infections of the hip and knee. J Bone Joint Surg 2011;93:1355-7.

2 Shea KG, Bloebaum RD, Avent JM, et al. Analysis of lymph nodes for polyethylene particles in patients who have had a primary joint replacement. J Bone Joint Surg 1996:78:497-504.

3 Treacy RBC, McBryde CW, Pynsent PB. Birmingham hip resurfacing arthroplasty: a minimum follow-up of five years. J Bone Joint Surg Br 2005;87-B:167-70. 
4 Steffen RT, Pandit HP, Palan J, et al. The five-year results of the Birmingham hip resurfacing arthroplasty: an independent series. J Bone Joint Surg $\mathrm{Br}$ 2008;90-B:436-41.

5 Long WT, Dorr L, Dorr LD, et al. An American experience with metal-on-metal tota hip arthroplasties: a 7-year follow-up study. J Arthroplasty 2004;19:29-34.

6 Dumbleton JH, Manley MT. Metal-on-Metal total hip replacement: what does the literature say? J Arthroplasty 2005;20:174-88.

7 Eswaramoorthy V, Moonot P, Kalairajah Y, et al. The Metasul metal-on-metal articulation in primary total hip replacement: clinical and radiological results at ten years. J Bone Joint Surg Br 2008;90-B:1278-83.

8 Grubl A, Weissinger $M$, Brodner $W$, et al. Serum aluminium and cobalt levels after ceramic-on-ceramic and metal-on-metal total hip replacement. J Bone Joint Surg $\mathrm{Br}$ 2006;88-B:1003-5.

9 Langton DJ, Jameson SS, Joyce TJ, et al. The effect of component size and orientation on the concentrations of metal ions after resurfacing arthroplasty of the hip. J Bone Joint Surg Br 2008;90-B:1143-51.

10 Sauve $P$, Mountney J, Khan T, et al. Metal ion levels after metal-on-metal ring total hip replacement: a 30-year follow-up study. J Bone Joint Surg Br 2007;89-B:586-90.

11 MacDonald SJ, McCalden RW, Chess DG, et al. Metal-on-metal versus polyethylene in hip arthroplasty: a randomized clinical trial. Clin Orthop Relat Res 2003;406: 282-96

12 Case CP, Langkamer VG, James $C$, et al. Widespread dissemination of metal debris from implants. J Bone Joint Surg Br 1994:76-B:701-12.

13 Visuri TI, Pukkala E, Pulkkinen P, et al. Cancer incidence and causes of death among total hip replacement patients: a review based on Nordic cohorts with a special emphasis on metal-on-metal bearings. Proc Inst Mech Eng [H] 2006:220:399-407.

14 Boardman DR, Middleton FR, Kavanagh TG. A benign psoas mass following metal-on-metal resurfacing of the hip. J Bone Joint Surg Br 2006;88-B:402-4.
15 Gruber FW, Bock A, Bock AF, et al. Cystic lesion of the groin due to metallosis: a rare long-term complication of metal-on-metal total hip arthroplasty. J Arthroplasty 2007;22:923-7.

16 Willert HG, Buchhorn GH, Fayyazi A, et al. Metal-on-metal bearings and hypersensitivity in patients with artificial hip joints. A clinical and histomorphological study. J Bone Joint Surg Am 2005;87:28-36.

17 Glyn-Jones S, Pandit H, Kwon YM, et al. Risk factors for inflammatory pseudotumour formation following hip resurfacing. J Bone Joint Surg $\mathrm{Br}$ 2009;91-B:1566-74.

18 Pandit H, Glyn-Jones S, McLardy-Smith $\mathrm{P}$, et al. Pseudotumours associated with metal-on-metal hip resurfacings. J Bone Joint Surg Br 2008;90-B:847-51.

19 Granchi DF, Cenni E, FAU, et al. - Sensitivity to implant materials in patients undergoing total hip replacement. —J Biomed Mater Res B Appl Biomater 2006;77:257-64.

20 Udofia IJ, Jin ZM. Elastohydrodynamic lubrication analysis of metal-on-metal hip-resurfacing prostheses. J Biomech 2003:36:537-44.

21 De Haan R, Pattyn C, Gill HS, et al. Correlation between inclination of the acetabular component and metal ion levels in metal-on-metal hip resurfacing replacement. J Bone Joint Surg Br 2008;90-B:1291-7.

22 Williams DF, Royle MF, Norton M.-Metal-on-metal hip resurfacing: the effect of cup position and component size on range of motion to impingement. J Arthroplasty 2009;24:144-51.

23 DeFrang RD, Guyer WD, Porter JM, et al. Synovial cyst formation complicating total hip arthroplasty: a case report. Clin Orthop Relat Res 1996:325:163-7.

24 Lin KH, Lo NN. Failure of polyethylene in total hip arthroplasty presenting as a pelvic mass. J Arthroplasty 2009;24:1144.e13-15.

25 Cooper HJ, Ranawat AS, Potter HG, et al. Early reactive synovitis and osteolysis afte total hip arthroplasty. Clin Orthop Relat Res 2010;468:3278-85.

Copyright 2014 BMJ Publishing Group. All rights reserved. For permission to reuse any of this content visit http://group.bmi.com/group/rights-licensing/permissions.

BMJ Case Report Fellows may re-use this article for personal use and teaching without any further permission.

Become a Fellow of BMJ Case Reports today and you can:

- Submit as many cases as you like

- Enjoy fast sympathetic peer review and rapid publication of accepted articles

- Access all the published articles

- Re-use any of the published material for personal use and teaching without further permission

For information on Institutional Fellowships contact consortiasales@bmjgroup.com

Visit casereports.bmj.com for more articles like this and to become a Fellow 